\title{
Safety Climate Perceptions in the Construction Industry of Saudi Arabia: The Current Situation
}

\author{
Ibrahim Mosly ${ }^{1, *(1)}$ and Anas A. Makki ${ }^{2}$ (0) \\ 1 Department of Civil Engineering, Faculty of Engineering-Rabigh Branch, King Abdulaziz University, \\ Jeddah 21589, Saudi Arabia \\ 2 Department of Industrial Engineering, Faculty of Engineering-Rabigh Branch, King Abdulaziz University, \\ Jeddah 21589, Saudi Arabia; nhmakki@kau.edu.sa \\ * Correspondence: ikmosly@kau.edu.sa; Tel.: +96-6126-952-000
}

Received: 13 August 2020; Accepted: 11 September 2020; Published: 15 September 2020

\begin{abstract}
Workers' wellbeing and safety is important in the construction industry due to the high risk of accidents. Safety climate development is a positive initial step toward raising the safety levels of construction practitioners. This study aims at revealing the factors influencing safety climate perceptions in the construction industry of Saudi Arabia. A set of extracted factors from the literature was validated and used to design a comprehensive questionnaire survey. Data was collected from 401 personnel working on 3 large construction project sites in Saudi Arabia. Descriptive statistics and the crosstabulation algorithm, Kendall's tau-b correlation test, were used to analyze the data. The study revealed a set of 13 factors influencing safety climate perceptions, which are: Supervision, guidance and inspection, appraisal of risks and hazards, social security and health insurance, workmate influences, management safety justice, management commitment to safety, education and training, communication, workers' safety commitment, workers' attitude toward health and safety, workers' involvement, supportive environment, and competence. The results also indicate the significant and anticipated role of top management in safety climate at sites. Implications of this study include assisting construction industry stakeholders to better understand and enhance safety climate, which in turn will lead to improved safety behavior, culture, motivation, and performance.
\end{abstract}

Keywords: safety climate; perception; construction; factors; Saudi Arabia

\section{Introduction}

Safety involves people's wellbeing and lives, making its implementation essential in construction projects [1]. Workers in the construction industry are in need of safety measures assimilation. The construction industry is a dangerous one, with high levels of injuries and death ratios compared to other industries [2]. Records show that the number of nonfatal occupational injuries in the U.S. construction industry in the year 2018 was 199,100 cases [3]. Furthermore, in the U.K., the average annual number of nonfatal occupational injuries in the construction industry from 2016-2019 was 54,000 cases [4]. Moreover, in Saudi Arabia, the construction industry accounted for the highest number of injuries among other industries with 16,968 cases in the year 2018 [5]. The significance of this industry cannot be overstated, as it delivers the infrastructure needed by the other industries and reflects the country's economic development level [6]. Disastrous safety accidents may occur if there is poor recognition of hazards and safety risks are underestimated [7]. Being a vital industry with high levels of safety risks, stakeholders' attention should focus on determining robust solutions. The lack of hazard recognition and the underestimation of safety risk are both widespread in the construction industry [7]. Workers in the construction industry experience high rates of injury and illness compared to those in other industries [8]. Training and research are tools that can assist in 
converting the situation of this industry. A large number of workers perceive production as a priority compared to managers, who have a better overall safety culture appraisal, and this may indicate that workers could take more risks to meet deadlines and expose themselves to injuries and illnesses [8]. Focus on raising safety awareness should start with the workers, who represent the weakest and most physically affected group in this industry. The widespread hiring of subcontractors in the construction industry has led to an increase in major safety concerns among general contractors, researchers, and health and safety organizations [9]. This emphasizes the need to conduct safety research to enhance safety levels at construction sites. Areas for safety enhancement can be identified through safety climate measurement [10]. Safety climate describes the perception, attitudes, and beliefs of workers on risk and safety and is mostly measured through questionnaire surveys to provide an idea on the current safety situation [11]. This makes safety climate an important initial intervention tool. An organization's safety climate should be measured regularly, as it will assist competent safety personnel in identifying and enhancing the policies, procedures, and practices of that organization [12]. Currently, it has become necessary for construction entities to embrace construction workers to assure a solid commitment to implementing safety policies and plans [13]. Safety participation and compliance significantly influence safety climate [12]. The training of competent safety teams with competent leaders at construction sites will have a positive influence on its safety. Safety leadership endorses constructive safety climate development, and this may result in improved construction safety [1].

The significance of safety climate is observed by its influence on safety behavior, safety motivation, safety culture, and safety performance. Firstly, there is an association between safety behavior and safety motivation. Several accidents are caused by unsafe actions, and this indicates that worker behavior is considered as an extremely significant workplace safety factor [14]. A study conducted in Saudi Arabia to examine the relationships among safety motivation, safety climate, safety behavior, and safety outcomes reported the following results: 1 . Safety behavior can be positively influenced by safety motivation because of the safety climate in the organization; 2 . safety behavior might forecast safety outcomes [15]. Another study in Australia has validated the significant role of supervisors' leadership and communication approach in creating a positive safety climate and influencing their workers' health and safety behaviors [16]. Once again, through supervisors' motivational communication, a positive safety climate can be created and as a result workers' safety behavior can be changed. Secondly, to further enhance safety climate, it is vital for an organization to have a positive safety culture, which also influences safety performance. Management should build communication channels and support workers with a positive organizational culture as well as ensure that their workers are protected, regardless of their background or employment type [17]. High-level supervisors have a significant role in facilitating the link between organizational safety climate and safety performance [18]. This means that an organization's team leader play an important role in safety climate. A study claims that project managers' skills will support the execution of targeted safety management tasks [1]. The application of these tasks can endorse safety climate, thus improving safety performance and eliminating unsafe situations along with preventing accidents [1]. Furthermore, increasing evidence shows that safety culture directly affects safety performance [8].

Research can influence the development and promotion of safety climate in the construction industry. One study emphasized the significance of enlightening positive safety climate, as it will lead to the enhancement of hazard recognition and safety risk perception [7]. Construction workers perceive risk perception as a job hindrance [19]. An example of a job hindrance is work pressure, and this causes a negative impact on both safety motivation and behavior [19]. Safety climate assists in changing workers' risk perception from a job hindrance to a job challenge [19]. Employees of companies with high levels of safety climate behave safely, and they perceive that they are encouraged to retain good safety practices in spite of high production pressure [20]. A study in Taiwan concluded that the safety climate perception of management is higher than that of laborers and that this difference can be used to improve strategies for enhancing safety climate on construction sites [17]. Improving the overall construction safety levels is the responsibility of construction managers, as they enhance safety 
perception by safety training and better practices [21]. Furthermore, better safety climate perception can be achieved when there is clear communication on rules [22]. Here, research studies emphasized the important role of team leaders and their means of communication with their teams to deliver safety climate.

Due to the high number of accidents in the construction industry of Saudi Arabia [6,23-25], several approaches should be investigated to enhance safety levels at Saudi Arabian construction sites, including safety climate. Currently, there is a lack of research in the area of safety climate in the construction industry of Saudi Arabia. Only a limited number of research studies explored safety climate in the construction industry of Saudi Arabia, including the studies done by Panuwatwanich et al. [15], Erogul and Alyami [26], Sanni-Anibire et al. [27], and Al-Haadir et al. [28]. Thus, there is a lack of research in the area of safety climate in the construction industry of Saudi Arabia, which necessitates its exploration in a comprehensive manner, with focus on identifying the factors influencing safety climate as a first step. This is because increasing empirical evidences links the improvement in safety climate with the improvement in construction site safety practices [29]. Furthermore, several studies found that safety climate is an important predictor of safety performance [30]. Nevertheless, a significant factor that expresses safety climate perception is the workers' perception of workplace hazards and risks, which is related to their safety climate perception of their company and their industry [31]. There is an association between the employees' safety climate perception and the safety of their workplace [32-35]. Furthermore, a number of project specific characteristics can influence the relation between safety climate and safety culture such as, project duration, project size, and contractor grade [36]. This could indicate that changing the employees' workplace may cause a change in their perception on safety climate depending on the level of safety of the workplace. Therefore, the evaluation of safety climate perception should be done based on the employees' risk perception as well as for their overall workplace safety climate perception.

This study will investigate the factors influencing safety climate in the construction industry based on the perception of industry practitioners. Furthermore, it will highlight the significant factors that in turn assist management level stakeholders in enhancing the safety levels of their organizations, leading to improved safety performance at construction sites.

\section{Materials and Methods}

A case study approach and quantitative research design was followed to achieve the objectives of this study. A set of 18 factors influencing safety climate in the construction industry was adopted from Mosly [2]. In their original literature review, the author only included articles from the Web of Science platform journal list. The search engine of the Web of Science platform is the most powerful and is used by many researchers to produce high-quality research [37]. A further extensive literature review of previous studies was made in the present study to verify and further support the 18 factor set adopted from Mosly [2] in a comprehensive manner that included all related studies from all available journals in the Saudi Digital Library (SDL). The SDL provides access to more than 300 global publishers, including Elsevier, Springer, Pearson, Wiley, Taylor \& Francis, McGraw-Hill, Yell University, Oxford University Press, and Harvard University Press [38]. The key words used in the search included "construction", "safety climate", and "factors". Additional references were added to the previous literature review by Mosly [2] compiling a total of 62 references used to identify the 18 factors influencing safety climate in the construction industry. This was made to enhance the reference list used to identify the influencing factors and make it more comprehensive. Those factors are broadly pertaining to the safety commitment, safety interaction, and safety support aspects of safety climate from both the management and workers' sides. Subsequently, the extracted set of factors was used to design a questionnaire survey by which detailed and comprehensive data were collected. The collected data included employee socio-demographic characteristics, ratings of factors influencing safety climate, and their overall rating of the project site safety climate. 
Employees were asked about their sociodemographic characteristics, including age, nationality, education level, occupation, trade specialty, and years of experience. Further, on a 5-point Likert scale (i.e., extremely important, important, neither, unimportant, extremely unimportant), they were asked to rate the importance of the extracted factors in influencing safety climate in their construction project sites. Finally, on a 5-point scale (i.e., excellent, good, neither, poor, extremely poor), they were also asked to evaluate the overall safety climate in their project sites.

Following a random sampling approach, cross-sectional data were collected in the period starting from July 2019 to January 2020 from site employees of 3 available, typically large (i.e., worth 140 million USD) construction projects in Saudi Arabia (see Table 1 for key safety parameters of sample projects). A random sample of 500 employees working at the 3 construction sites of ongoing projects was targeted. Four hundred and one employees responded and successfully completed the questionnaire, representing a response rate of $80.2 \%$. Data was collected via site visits, face-to-face interviews, and Google Forms for ensuring a single response from each respondent, recording the collected data, and initial database set-up. All construction site employees of all types, levels and backgrounds had an equal probability of participating in the survey and being in the sample. Ethical approval from the ethical committee at the Center of Excellence in Genomic Medicine Research, King Abdulaziz University, was obtained for conducting this research questionnaire survey. (HA-02-J003)

Table 1. Key safety parameters of sample projects.

\begin{tabular}{cccc}
\hline Safety Parameters & $\begin{array}{c}\text { Project } \mathbf{1} \\
\mathbf{( \$ 9 7} \text { million) }\end{array}$ & $\begin{array}{c}\text { Project 2 } \\
\text { (\$26 million) }\end{array}$ & $\begin{array}{c}\text { Project 3 } \\
\text { (\$27 million) }\end{array}$ \\
\hline Number of Accidents Occurred & 24 & 20 & 11 \\
Written Safety Policy & $\sqrt{ }$ & $\sqrt{ }$ & X \\
Availability of Competent Safety Teams & $\sqrt{ }$ & $\sqrt{ }$ & $\sqrt{ }$ \\
Availability of Safety Instructions and Guidelines & $\sqrt{ }$ & $\sqrt{ }$ & $\sqrt{ }$ \\
Availability of Personnel Protective Equipment & $\sqrt{ }$ & $\sqrt{ }$ & $\sqrt{ }$ \\
Provision of Safety Education and Training for & $\sqrt{ }$ & $\sqrt{ }$ & $\sqrt{ }$ \\
Employees & $\sqrt{ }$ & & \\
\hline
\end{tabular}

The Statistical Package for the Social Sciences SPSS version 23.0 (SPSS Inc.; Chicago, IL, USA) [39], was used to analyze the collected data. Descriptive statistics was used to analyze the sociodemographic characteristics of the respondents, and their perceived ratings on the safety climate influencing factors. Additionally, as the collected data were ordinal, the crosstabulation algorithm, Kendall's tau-b correlation test $[40,41]$ was used to reveal the statistically significant influencing factors that act as predominant determinants of the perceived overall safety climate evaluation of construction sites. Kendall's tau-b is a non-parametric test used to measure the ordinal correlation between variables based on pairs of ranked data representing the level of concordance between them. Therefore, the correlation coefficients using [39] and in accordance to [41] were calculated using the following algorithm (Equations (1)-(7)):

Let,

$X_{i}$ : Distinct values of row variable arranged in ascending order $\left(X_{1}<X_{2}<\ldots<X_{R}\right)$,

$Y_{j}$ : Distinct values of column variable arranged in ascending order $\left(Y_{1}<Y_{2}<\ldots<Y_{C}\right)$,

$f_{i j}$ : Sum of cell weights for cases in cell $(i, j)$,

$c_{j}: \sum_{i=1}^{R} f_{i j}$, the $j$ th column subtotal,

$r_{i}: \sum_{j=1}^{C} f_{i j}$, the $i$ th row subtotal,

$W: \sum_{j=1}^{C} c_{j}=\sum_{i=1}^{R} r_{i}$, the grand total,

$$
D_{r}=W^{2}-\sum_{i=1}^{R} r_{i}^{2}
$$




$$
\begin{gathered}
D_{c}=W^{2}-\sum_{j=1}^{C} c_{j}^{2}, \\
C_{i j}=\sum_{h<i} \sum_{k<j} f_{h k}+\sum_{h>i} \sum_{k>j} f_{h k}, \\
D_{i j}=\sum_{h<i} \sum_{k>j} f_{h k}+\sum_{h>i} \sum_{k<j} f_{h k}, \\
P=\sum_{i, j} f_{i j} C_{i j}, \\
Q=\sum_{i, j} f_{i j} D_{i j},
\end{gathered}
$$

where in SPSS,

$P:$ is double the number of concordant pairs.

$Q$ : is double the number of discordant pairs.

$D_{r}$ : is double $P+Q+X_{0}$ (the number of concordant pairs, discordant pairs, and pairs on which the row variable is tied).

$D_{c}$ : is double $P+Q+Y_{0}$ (the number of concordant pairs, discordant pairs, and pairs on which the column variable is tied).

accordingly, Kendall's Tau-b correlation coefficient is given by Equation (7):

$$
\tau_{b}=\frac{P-Q}{\sqrt{D_{r} D_{c}}}
$$

The results of the analysis along with a discussion are presented subsequently.

\section{Results and Discussion}

The resulting set of extracted and verified safety climate factors from the extensive literature review process is listed in Table 2 including their supporting references, and a brief description of each of them is presented in Table 3. The most mentioned influencing factor in the literature review with respect to safety climate in the construction industry was management commitment to safety. This emphasizes the important role of management in construction site safety and safety climate effect. Moreover, the factors communication, supervision, guidance and inspection, education and training, and safety rules, and procedures, were also highly mentioned in related studies. It also indicated their major impact on construction industry safety and safety climate. The least mentioned safety climate factor was social security and health insurance, as it was only mentioned in one study.

Table 4 presents the descriptive statistics of the collected sample of employee's sociodemographic characteristics. This includes the sample size and percentage of each sociodemographic subgroup in the collected sample. The demographics included: Age, nationality, education, occupation, years of experience, and trade specialty. The descriptive statistics presented in Table 4 show that the surveyed construction employees in the sample are distributed among eight age categories, and most of them were aged between 30 and 40 years. Furthermore, they were mainly from Pakistan, Egypt, Yemen, India, and Syria, respectively. The respondents' education level ranged from illiterates to bachelor's degree, with the largest subgroup being employees with secondary education level. Among six construction industry occupations, workers represented a large subgroup of the sample. Moreover, most of the employees in the sample demonstrated a work experience ranging from new employees to employees with 11 to 15 years of experience. Lastly, among 14 construction industry specialties, carpenters represented the largest portion of the used sample in this study. The sociodemographic 
subgroup sample sizes and percentages are considered representative of many typical construction project sites in Saudi Arabia.

Table 2. List of extracted factors influencing safety climate at construction project sites from the previous literature.

\begin{tabular}{ccc}
\hline Safety Climate Factor * & References & $\begin{array}{c}\text { Number of } \\
\text { References }\end{array}$ \\
\hline Management Commitment to Safety & {$[10,12,15,18,29,30,32,42-78]$} & 44 \\
Communication & {$[12,15,30,42-44,46,51,54,55,58-64,69,76,77,79-87]$} & 29 \\
Supervision, Guidance, and Inspection & {$[18,29,32,43,44,46,47,49,50,53,55,57,58,61,63,65,67$,} & 26 \\
Education and Training & $71,72,74,75,80,88-91]$ & 23 \\
Safety Rules, and Procedures & {$[12,32,44,46,47,52,56-58,60-62,69,73,75-77,82,83,86$,} & 23 \\
Co-worker Influence & $92-94]$ & 19 \\
Workers' Involvement & {$[10,15,32,36,42-49,53,55,57,58,60,61,69,73,76,79,86]$} & 17 \\
Work Pressure and Intensity & {$[12,18,29,30,32,42,47,48,50,51,64,71,72,75,79,80,89$,} & 15 \\
Supportive Environment & $90,95]$ & 12 \\
Safety Resources & {$[10,12,29,30,32,43,45,46,48,50,55,56,58,60-62,71]$} & 9 \\
Appraisal of Risk and Hazard & {$[12,15,43,49,55,56,58,60,61,66,67,69,73,79,80]$} & 7 \\
Competence & {$[10,12,30,43,47,48,50,51,69,73,76,81]$} & 6 \\
Worker's & {$[43,50,51,55-57,60,76,84]$} & 6 \\
Adtitude toward Health and Safety & {$[12,30,32,42,54,57,79]$} & 5 \\
Management Safety Justice & {$[15,32,43,54,55,58]$} & 5 \\
Safety Value and Reward System & {$[12,15,32,43,51,55]$} & 4 \\
Social Security and Health Insurance & {$[29,51,54,59,84]$} & 3 \\
\hline
\end{tabular}

* Adopted and enhanced from Mosly [2].

Table 3. Description of safety climate factors.

\begin{tabular}{|c|c|c|}
\hline Safety Climate Factor & Description & References \\
\hline $\begin{array}{l}\text { Management Commitment } \\
\text { to Safety }\end{array}$ & The priority level and care that management dedicate to workers' safety. & {$[12,15,43]$} \\
\hline Communication & Effective communication by management and workers' feedback. & {$[12,15,43]$} \\
\hline $\begin{array}{l}\text { Supervision, Guidance, } \\
\text { and Inspection }\end{array}$ & $\begin{array}{c}\text { Assistance and assurance that a safety program is fully implemented } \\
\text { on site. }\end{array}$ & {$[18,29,43]$} \\
\hline Education and Training & $\begin{array}{c}\text { Information, instructions, and learning materials provided to workers } \\
\text { on safety. }\end{array}$ & {$[58,60,93]$} \\
\hline Safety Rules, and Procedures & Safety rules and procedures set by the organization. & {$[12,43,58]$} \\
\hline Co-worker Influence & $\begin{array}{c}\text { The influence of co-worker's perceptions/practices on each other in } \\
\text { terms of safety aspects. }\end{array}$ & {$[12,29,42]$} \\
\hline Workers' Involvement & Involvement and contribution of workers in safety activities. & {$[12,15,43]$} \\
\hline Work Pressure and Intensity & $\begin{array}{l}\text { The level at which workers feel pressurized to complete a task within a } \\
\text { specific deadline. }\end{array}$ & {$[15,43,58]$} \\
\hline $\begin{array}{l}\text { Worker's Attitude toward } \\
\text { Health and Safety }\end{array}$ & $\begin{array}{l}\text { The perception of the worker towards aspects of health and safety, and } \\
\text { the willingness degree to risk taking. }\end{array}$ & {$[12,43,47]$} \\
\hline Supportive Environment & An overall safety trust and support between a group of employees. & {$[43,50,76]$} \\
\hline Safety Resources & $\begin{array}{l}\text { Sufficient safety resources allocated by management for the safe } \\
\text { conduct of tasks at site. }\end{array}$ & {$[12,32,42]$} \\
\hline Appraisal of Risk & The ability to assess risks and hazards. & {$[32,43,55]$} \\
\hline Competence & $\begin{array}{c}\text { The general background of workers' knowledge, training, qualification, } \\
\text { and skills. }\end{array}$ & {$[15,43,55]$} \\
\hline $\begin{array}{l}\text { Workers' Commitment } \\
\text { to Safety }\end{array}$ & $\begin{array}{c}\text { The priority level and care that workers dedicate to their own and } \\
\text { others safety on site. }\end{array}$ & [51] \\
\hline $\begin{array}{l}\text { Adequacy of } \\
\text { Safety Procedures }\end{array}$ & $\begin{array}{c}\text { Content of safety procedures being clear, comprehensive, correct, and } \\
\text { reflect actual safety needs. }\end{array}$ & {$[70,83]$} \\
\hline Management Safety Justice & $\begin{array}{c}\text { The degree of quality to which the management can deal fairly with } \\
\text { workers involved in safety accidents. }\end{array}$ & [51] \\
\hline $\begin{array}{l}\text { Safety Value and } \\
\text { Reward System }\end{array}$ & Incentives to encourage workers on safe practices and good behavior. & [80] \\
\hline $\begin{array}{l}\text { Social Security and } \\
\text { Health Insurance }\end{array}$ & Providing workers with legal contracts and medical insurance. & [80] \\
\hline
\end{tabular}


Table 4. Research sample sociodemographic $(n=401)$.

\begin{tabular}{|c|c|c|c|c|c|c|c|}
\hline Characteristic & Groups & $n$ & $\%$ & Characteristic & Groups & $n$ & $\%$ \\
\hline \multirow{8}{*}{$\begin{array}{c}\text { Age } \\
\text { (years) }\end{array}$} & $18-20$ & 2 & 0.50 & \multirow{6}{*}{ Occupation } & Worker & 294 & 73.31 \\
\hline & $21-25$ & 51 & 12.72 & & Technician & 15 & 3.74 \\
\hline & $26-30$ & 57 & 14.20 & & Supervisor & 50 & 12.50 \\
\hline & $31-35$ & 89 & 22.20 & & Architect & 3 & 0.75 \\
\hline & $36-40$ & 105 & 26.20 & & Engineer & 29 & 7.20 \\
\hline & $41-45$ & 65 & 16.20 & & Manager & 10 & 2.50 \\
\hline & $46-50$ & 23 & 5.74 & - & - & - & - \\
\hline & More than 50 & 9 & 2.24 & \multirow{5}{*}{$\begin{array}{c}\text { Experience } \\
\text { (years) }\end{array}$} & $0-5$ & 108 & 26.93 \\
\hline \multirow[t]{4}{*}{-} & - & - & - & & $6-10$ & 134 & 33.41 \\
\hline & Sudanese & 3 & 0.75 & & $11-15$ & 107 & 26.70 \\
\hline & Philippine & 3 & 0.75 & & $16-20$ & 35 & 8.73 \\
\hline & Bangladeshi & 6 & 1.50 & & More than 20 & 17 & 4.23 \\
\hline \multirow{7}{*}{ Nationality } & Somali & 7 & 1.75 & - & - & - & - \\
\hline & Syrian & 50 & 12.47 & \multirow{14}{*}{$\begin{array}{c}\text { Trade } \\
\text { specialty }\end{array}$} & Carpenter & 100 & 24.93 \\
\hline & Indian & 55 & 13.71 & & Blacksmith & 82 & 20.45 \\
\hline & Yemeni & 58 & 14.50 & & Bricklaying & 39 & 9.72 \\
\hline & Egyptian & 90 & 22.40 & & Painter & 5 & 1.25 \\
\hline & Pakistani & 129 & 32.17 & & Plumbing & 34 & 8.50 \\
\hline & - & & & & Cement and concrete & 31 & 7.73 \\
\hline \multirow{6}{*}{ Education } & Illiterate & 70 & 17.45 & & Crane operator & 7 & 1.75 \\
\hline & Elementary & 68 & 16.96 & & Surveyor & 9 & 2.24 \\
\hline & Intermediate & 73 & 18.20 & & Mechanical & 4 & 1.00 \\
\hline & Secondary & 99 & 24.69 & & Architecture & 3 & 0.75 \\
\hline & Diploma & 31 & 7.70 & & Electrical & 9 & 2.24 \\
\hline & Bachelor & 60 & 15.00 & & Administration & 15 & 3.74 \\
\hline- & - & - & - & & Civil & 50 & 12.50 \\
\hline- & - & - & - & & $\begin{array}{l}\text { Safety and quality } \\
\text { control }\end{array}$ & 13 & 3.20 \\
\hline
\end{tabular}

The employees in the collected sample were asked to rate, on a 5-point scale, the importance of the 18 extracted factors influencing safety climate to their construction project site. Table 5 presents the descriptive statistics of their ratings, including the distribution of the sample size and percentage of each level of importance for each influencing factor. Furthermore, it includes the overall mean and standard deviation along with the rank and level of each factor. After ranking the factors based on their mean, the factors supervision and guidance, education and training, and management commitment to safety, were ranked, in order, as the top three influencing factors on safety climate in construction project sites of Saudi Arabia. Moreover, these factors received a rating level of "extremely important" based on their mean scores. This indicates the important role of the top management in facilitating safety climate perception in employees. This can be accomplished by providing specialized safety supervision and guidance through appointing competent safety personnel for construction site auditing and inspection, as well as offering continued safety guidance. Supervisors have significantly higher safety climate perception compared to workers [96]. They conduct a significant role in providing workers with needed safety support through ongoing interaction, such as demonstrating how to perform tasks safely as well as guaranteeing that rewards are provided for accomplishing safety targets on site [97]. Due to work pressure and higher standard of safety performance, supervisors are more subjected to psychological stress than workers [96]. Automatic computer vision-based techniques can assist supervisors in their daily tasks and reduce the amount of stress that they face. For instance, a study has tested and validated the use of automatic computer vision-based techniques to monitor workers crowdedness for the purpose of proactive safety management [98]. This assisted in addressing the issues caused by high crowdedness that includes hazardous working environments, negative workers' behavior, lack of concern for safety climate, and low productivity [98]. Moreover, employees should be offered safety training and workshops at all levels, along with the distribution of safety 
educational material. Theoretical and practical training programs are important in improving safety behavior [99]. It is necessary to provide less experienced workers with sufficient safety training, as more experienced workers are cautious toward hazards due to their safety knowledge [100]. Building information modelling applications that focus on safety education and training can also augment safety climate [101]. Also, new training methods such as safety training park can be adopted to develop safety climate within organizations [102]. Strong commitment to safety measures by management will require sufficient financial and moral support. A study specified the optimal safety investment to be $1 \%$ of the total project value [103]. Furthermore, a study has identified the safety climate factor of safety management rules and regulations as the most effective safety factor [104]. As stated previously in the introduction section, organizations' safety policies, procedures, and practices must be measured regularly, which reflects management commitment to safety. Generally, the development, fund, and implementation of policies should be comprehensive with local to national scale interdisciplinary efforts [105]. The remaining influencing factors on safety climate received a rating level of "important" based on their ranked mean scores. Based on the overall weighted mean of the 18 factors, the overall rating level of all factors in the questionnaire was "important", indicating an overall agreement of the surveyed construction site employees on the importance of the 18 factors in influencing the safety climate at construction sites in Saudi Arabia. Given that workers represent the largest subgroup in the sample (i.e., 73.3\%) (Table 4) and from the ranking of factors in the questionnaire (Table 5), it is apparent that workers indicate the extremely important role of management and the anticipated top-down direction of safety assimilation on construction sites for a better safety climate from their perspective. Although the safety climate factor social security and health insurance was only mentioned in one reference in the literature review (see Table 2), the study participants ranked it in fourth place, giving it high priority among the influencing safety climate factors in the context of the Saudi Arabian construction industry. The participants viewed social security and health insurance as a significant element for attaining safety climate. Despite that the communication safety climate factor was ranked 17 out of the 18 influencing factors, it was still important. This might be due to the fact that most workers in the construction industry of Saudi Arabia are expatriates of diverse nationalities (see Table 4) and they see communication as a major obstacle and an important safety climate element. Supervisors play a vital role in building safety climate through safety communication within a group of workers, which in turn changes workers' safety compliance and behaviors [106]. Synergistic benefits can be achieved by positive safety climate and maintaining high levels of safety communication [107]. In fact, a study resulted in confirming that the link between safety climate and safety outcomes is totally arbitrated by safety communication [108]. An approach such as the lean project delivery system can be used to enhance positive safety climate in the project, as it can integrate stakeholder teams and improve communications [109]. Also, information and communication technology systems can assist in improving safety and quality [110]. A pilot study that investigated the use of information and communication technology systems in the form of a mobile application presented an enhancement of $30 \%$ in quality and a reduction of $90 \%$ in unsafe behaviors [110].

As mentioned earlier, the same construction site employees were also asked to evaluate the overall safety climate in their construction project site on a 5-point scale (i.e., excellent, good, neither, poor, extremely poor). Table 6 provides descriptive statistics of their perceived evaluations, including the distribution of the sample size and percentage of each evaluation level of safety climate on their construction site. It also shows the overall mean and standard deviation along with the overall evaluation level. Table 6 shows that the overall safety climate level on construction sites where the surveyed employees work is "good", based on the mean of their evaluations. A limited number of participants perceived the safety climate levels of their construction sites to "poor" or "extremely poor". 
Table 5. Descriptive statistics of factors influencing safety climate $(n=401)$.

\begin{tabular}{|c|c|c|c|c|c|c|c|c|c|c|}
\hline \multirow{2}{*}{ Factor } & & \multicolumn{5}{|c|}{ Level } & \multirow{2}{*}{ Mean } & \multirow{2}{*}{$\begin{array}{l}\text { Standard } \\
\text { Deviation }\end{array}$} & \multirow{2}{*}{ Rank } & \multirow{2}{*}{ Level $^{\mathrm{a}}$} \\
\hline & & 5 & 4 & 3 & 2 & 1 & & & & \\
\hline \multirow{2}{*}{$\begin{array}{l}\text { Supervision, guidance, } \\
\text { and inspection }\end{array}$} & $n$ & 204 & 127 & 63 & 7 & 0 & \multirow{2}{*}{4.32} & \multirow{2}{*}{0.798} & \multirow{2}{*}{1} & \multirow{2}{*}{5} \\
\hline & $\%$ & 50.9 & 31.7 & 15.7 & 1.7 & 0.0 & & & & \\
\hline \multirow{2}{*}{ Education and training } & $n$ & 206 & 129 & 53 & 11 & 2 & \multirow{2}{*}{4.31} & \multirow{2}{*}{0.840} & \multirow{2}{*}{2} & \multirow{2}{*}{5} \\
\hline & $\%$ & 51.4 & 32.2 & 13.2 & 2.7 & 0.5 & & & & \\
\hline \multirow{2}{*}{$\begin{array}{l}\text { Management commitment } \\
\text { to safety }\end{array}$} & $n$ & 186 & 133 & 68 & 12 & 2 & \multirow{2}{*}{4.22} & \multirow{2}{*}{0.867} & \multirow{2}{*}{3} & \multirow{2}{*}{5} \\
\hline & $\%$ & 46.4 & 33.2 & 17.0 & 3.0 & 0.5 & & & & \\
\hline \multirow{2}{*}{$\begin{array}{l}\text { Social security and } \\
\text { health insurance }\end{array}$} & $n$ & 184 & 132 & 66 & 16 & 3 & \multirow{2}{*}{4.19} & \multirow{2}{*}{0.903} & & \\
\hline & $\%$ & 45.9 & 32.9 & 16.5 & 4.0 & 0.7 & & & 4 & 4 \\
\hline Appraisal of risks and hazards & $n$ & 148 & 167 & 68 & 18 & 0 & & & & \\
\hline Appraisal of risks and hazards & $\%$ & 36.9 & 41.6 & 17.0 & 4.5 & 0.0 & 4.11 & 0.841 & 5 & 4 \\
\hline & $n$ & 142 & 168 & 71 & 15 & 5 & & & & \\
\hline Competence & $\%$ & 35.4 & 41.9 & 17.7 & 3.7 & 1.2 & 4.06 & 0.889 & 6 & 4 \\
\hline Workers' safety commitment & $n$ & 146 & 145 & 83 & 24 & 3 & 401 & 0938 & 7 & \\
\hline & $\%$ & 36.4 & 36.2 & 20.7 & 6.0 & 0.7 & 4.01 & 0.938 & 7 & 4 \\
\hline Manarement safety iustice & $n$ & 149 & 127 & 95 & 23 & 7 & 207 & 0909 & 8 & 4 \\
\hline Management sarety justice & $\%$ & 37.2 & 31.7 & 23.7 & 5.7 & 1.7 & 3.97 & 0.998 & 8 & 4 \\
\hline Safety resources & $n$ & 146 & 136 & 79 & 31 & 9 & & & & \\
\hline safety resources & $\%$ & 36.4 & 33.9 & 19.7 & 7.7 & 2.2 & 3.95 & 1.035 & 9 & 4 \\
\hline & $n$ & 87 & 173 & 104 & 32 & 5 & & & & \\
\hline Work pressure and intensity & $\%$ & 21.7 & 43.1 & 25.9 & 8.0 & 1.2 & 3.76 & 0.923 & 10 & 4 \\
\hline & $n$ & 76 & 185 & 109 & 29 & 2 & & & & \\
\hline Supportive environment & $\%$ & 19.0 & 46.1 & 27.2 & 7.2 & 0.5 & 3.76 & 0.860 & 11 & 4 \\
\hline Safety rules and procedures & $n$ & 103 & 143 & 103 & 42 & 10 & 372 & 1039 & 12 & 4 \\
\hline & $\%$ & 25.7 & 35.7 & 25.7 & 10.5 & 2.5 & 3.72 & 1.039 & 12 & 4 \\
\hline Safety value and reward system & $n$ & 80 & 148 & 133 & 40 & 0 & 367 & & 13 & \\
\hline Salety value and rewara systemt & $\%$ & 20.0 & 36.9 & 33.2 & 10.0 & 0.0 & 3.67 & 0.907 & 13 & 4 \\
\hline Adequacy of procedures & $n$ & 70 & 141 & 128 & 46 & 16 & & & & \\
\hline Adequacy or procedures & $\%$ & 17.5 & 35.2 & 31.9 & 11.5 & 4.0 & 3.51 & 1.035 & 14 & 4 \\
\hline & $n$ & 53 & 146 & 148 & 50 & 4 & & & & \\
\hline Workers' involvement & $\%$ & 13.2 & 36.4 & 36.9 & 12.5 & 1.0 & 3.48 & 0.908 & 15 & 4 \\
\hline & $n$ & 60 & 133 & 136 & 67 & 5 & & & & \\
\hline Workmate influences & $\%$ & 15.0 & 33.2 & 33.9 & 16.7 & 1.2 & 3.44 & 0.978 & 6 & 4 \\
\hline Communication & $n$ & 52 & 145 & 135 & 64 & 5 & 244 & 0950 & 17 & 4 \\
\hline Communication & $\%$ & 13.0 & 36.2 & 33.7 & 16.0 & 1.2 & 3.44 & 0.950 & 17 & 4 \\
\hline Workers' attitude toward health & $n$ & 28 & 159 & 170 & 42 & 2 & 342 & 0790 & 18 & 4 \\
\hline and safety & $\%$ & 7.0 & 39.7 & 42.4 & 10.5 & 0.5 & 3.42 & 0.790 & 18 & 4 \\
\hline Weighted Mean & & & & & & & 3.85 & & verall & 4 \\
\hline Standard Deviation & & & & & & & & 0.43 & Level & 4 \\
\hline
\end{tabular}

Level: 5 = Extremely important; $4=$ important; 3 = neither; $2=$ unimportant; $1=$ extremely unimportant. ${ }^{\text {a }}$ Level based on a score interval mean on an equal interval lengths of $0.8: 5=(4.20,5), 4=(3.40,4.20), 3=(2.60,3.40)$, $2=(1.80: 2.60), 1=(1: 1.80)$.

Table 6. Descriptive statistics of perceived overall safety climate ratings $(n=401)$.

\begin{tabular}{|c|c|c|c|c|c|c|c|c|c|}
\hline \multirow{3}{*}{$\begin{array}{c}\text { Safety } \\
\text { Climate } \\
\text { Ratings }\end{array}$} & & \multicolumn{5}{|c|}{ Level } & \multirow{2}{*}{ Mean } & \multirow{2}{*}{$\begin{array}{l}\text { Standard } \\
\text { Deviation }\end{array}$} & \multirow{2}{*}{$\begin{array}{l}\text { Overall } \\
\text { Level }^{\mathrm{a}}\end{array}$} \\
\hline & & 5 & 4 & 3 & 2 & 1 & & & \\
\hline & $\begin{array}{l}n \\
\%\end{array}$ & $\begin{array}{c}65 \\
16.21\end{array}$ & $\begin{array}{c}202 \\
50.37\end{array}$ & $\begin{array}{c}103 \\
25.69\end{array}$ & $\begin{array}{c}29 \\
7.23\end{array}$ & $\begin{array}{c}2 \\
0.50\end{array}$ & 3.75 & 0.831 & 4 \\
\hline
\end{tabular}

Level: 5 = Excellent; 4 = good; $3=$ neither; $2=$ poor; $1=$ extremely poor. ${ }^{\text {a }}$ Overall level based on a score interval mean on an equal interval lengths of $0.8: 5=(4.20,5), 4=(3.40,4.20), 3=(2.60,3.40), 2=(1.80: 2.60), 1=(1: 1.80)$. 
Subsequently, to reveal the statistically significant influencing factors that act as predominant determinants of the perceived overall safety climate evaluation of construction sites, Kendall's tau-b correlation test was conducted between the perceived overall safety climate evaluation of construction sites (Table 6) and the perceived importance of each of the 18 factors influencing safety climate (Table 5). The results of the analysis, presented in Table 7 , show the statistically significant correlations between the factors influencing safety climate perceived importance and the perceived overall safety climate evaluation. Significant factors are ranked based on their Kendall's tau-b values and their associated level of statistical significance. Thirteen out of 18 influencing factors on safety climate were significant predominant determinants of perceived safety climate evaluation at their construction sites. The factors were supervision and guidance, appraisal of risks and hazards, social security and health insurance, workmate influences, management safety justice, management commitment to safety, education and training, and communication, demonstrating a statistical significance level of $p<0.001$. Whereas the factors: Workers safety commitment, workers' attitude toward health and safety, workers' involvement, supportive environment, and competence demonstrated statistical significance levels of $p<0.01$. We noted that most of the influencing factors demonstrating $p$-values of $<0.001$ are related to the top management. On the other hand, we also noted that most of the influencing factors demonstrating $p$-values $<0.01$ are related to the workers. This indicates the importance of the support provided by management to construction site employees in many forms, the role of management commitment to safety, and then safety aspects pertaining to workers in determining safety climate level on construction sites. Table 7 presents the significant factors influencing safety climate in the construction industry of Saudi Arabia.

Table 7. Statistically significant correlations between the perceived importance of factors influencing safety climate and the perceived overall safety climate ratings.

\begin{tabular}{cc}
\hline Factors Influencing Safety Climate in the Construction Industry of Saudi Arabia & Kendall's tau-b \\
\hline Supervision and guidance & $0.208^{* * *}$ \\
Appraisal of risks and hazards & $0.196^{* * *}$ \\
Social security and health insurance & $0.191^{* * *}$ \\
Workmate influences & $0.180^{* * *}$ \\
Management safety justice & $0.181^{* * *}$ \\
Management commitment to safety & $0.173^{* * *}$ \\
Education and training & $0.166^{* * *}$ \\
Communication & $0.160^{* * *}$ \\
Workers' safety commitment & $0.144^{* *}$ \\
Workers' attitude toward health and safety & $0.143^{* *}$ \\
Workers' involvement & $0.120^{* *}$ \\
Supportive environment & $0.125^{* *}$ \\
Competence & $0.123^{* * *}$ \\
\hline
\end{tabular}

${ }^{* *} p<0.01,{ }^{* * *} p<0.001$.

Construction industry stakeholders should focus in-depth on these factors to raise safety climate levels among their employees. This will lead to raising the safety perception at construction sites and as a result increase the safety levels by reducing the rate of accidents. Furthermore, these factors represent the datum for future research in safety climate in the construction industry of Saudi Arabia. More studies could be developed based on these influencing factors.

\section{Conclusions}

In this study, the aim was to reveal factors influencing safety climate in the construction industry of Saudi Arabia from the industry practitioner's perspective. The study has revealed a total of 13 statistically significant influencing factors that act as predominant determinants of the overall safety climate evaluation of construction sites. These influencing factors are: Supervision and guidance, appraisal of risks and hazards, social security and health insurance, workmate influences, management 
safety justice, management commitment to safety, education and training, communication, workers' safety commitment, workers' attitude toward health and safety, workers' involvement, supportive environment, and competence. The results of this study indicate the significant and anticipated role of top management in the construction industry of Saudi Arabia to play in safety climate from construction site employees' point of view. This also provides further evidence and emphasis on the safety climate literature on the need for the application of a top-down safety climate assimilation approach. Furthermore, despite the low number of previous studies considering social security and health insurance as an important influencing factor of safety climate, our study reveals the significance of this factor in influencing safety climate in the construction industry of Saudi Arabia. This finding provides evidence for the construction industry practitioners' perceived significance of social security and health insurance, which could be attributed to the environment of the construction industry being project-based and a high safety risk industry.

The results of this study will assist stakeholders of the construction industry of Saudi Arabia to better understand and enhance safety climate in their organizations, which in turn will lead to the development of safety performance on construction sites. This better understanding can be reached using the revealed set of factors with their perceived importance describing the current situation in construction sites. Furthermore, the revealed correlations of the set of influencing factors with perceived safety climate evaluations in construction sites from the viewpoint of their employees, assist in determining areas of improvement to enhance safety climate. Moreover, the presented statistically significant factors influencing safety climate in the construction industry of Saudi Arabia can be used in many future research directions such as safety climate, safety performance, and safety leadership in the construction industry context, to mention just a few.

It is recommended for organizations involved in the construction industry of Saudi Arabia to increase the emphasis on enhancing safety climate perception on their sites. This could be attained through different means, including the adoption and implementation of novel techniques and systems that support supervision and guidance, offering of extensive training programs, and the development of encouraging safety policies, procedures, and practices that demonstrate the management commitment to safety.

Results of this study are limited to representing patterns within the collected data (July 2019 to January 2020) from employees working on 3 large construction sites in Saudi Arabia. Despite that the 3 large construction sites are deemed representative of typical construction sites in Saudi Arabia, reconducting the study and collecting data from other construction sites at a different temporal context will further confirm the results of this study. Moreover, despite the fairly large sample size used in this study (i.e., $n=401$ ), conducting the study using a larger sample size is another future research direction to confirm the revealed set of influencing factors of safety climate. Furthermore, the next step to this work is to categories or cluster the revealed set of influencing factors using a dimension reduction statistical approach to reveal the main latent components of safety climate perceptions in construction sites. Moreover, studying the safety climate perceptions of different sociodemographic groups of construction site employees to reveal the influence of sociodemographic characteristics on safety climate perceptions is also a future research direction. Finally, developing a safety climate prediction model using the revealed set of factors in this study that can predict perception levels of construction site employees is another future research direction.

Author Contributions: Conceptualization, I.M. and A.A.M.; methodology, I.M. and A.A.M.; software, A.A.M.; validation, I.M. and A.A.M.; formal analysis, A.A.M.; investigation, I.M. and A.A.M.; resources, I.M. and A.A.M.; data curation, I.M. and A.A.M.; writing-original draft preparation I.M. and A.A.M.; writing—review and editing, I.M. and A.A.M.; visualization, I.M. and A.A.M.; supervision, I.M. and A.A.M.; project administration I.M. and A.A.M. All authors have read and agreed to the published version of the manuscript.

Funding: This research received no external funding.

Acknowledgments: The authors would like to acknowledge the respondents of questionnaire survey, without whom, the completion of this research study would not be possible. 
Conflicts of Interest: Collected respondents' information in the questionnaire survey are confidential and were only used for the purpose of this research study. The authors declare no conflict of interest.

\section{References}

1. Sunindijo, R.; Zou, P. How project manager's skills may influence the development of safety climate in construction projects. Int. J. Proj. Organ. Manag. 2012, 4, 286-301. [CrossRef]

2. Mosly, I. Factors Influencing Safety Climate in the Construction Industry: A Review. Int. J. Constr. Eng. Manag. 2019, 8, 105-109. [CrossRef]

3. BLS. Employer-Reported Workplace Injuries and Illnesses-2018. Available online: https://www.bls.gov/ news.release/archives/osh_11072019.pdf (accessed on 2 September 2020).

4. HSE. Construction Statistics in Great Britain. 2019. Available online: https://www.hse.gov.uk/statistics/ industry/construction.pdf (accessed on 2 September 2020).

5. GASTAT. Distribution of Work Injuries According to the Economic Activity of the Establishment. Available online: https://www.stats.gov.sa/en/6333 (accessed on 2 September 2020).

6. Suresh, S.; Renukappa, S.; Alghanmi, I.; Mushatat, S.; Olayinka, R. Examining the Satisfaction Level of Construction Workers Regarding Safety Management in the Kingdom of Saudi Arabia. J. Constr. Dev. Ctries. 2017, 22, 97-113. [CrossRef]

7. Pandit, B.; Albert, A.; Patil, Y.; Al-Bayati, A. Impact of safety climate on hazard recognition and safety risk perception. Saf. Sci. 2019, 113, 44-53. [CrossRef]

8. Gilkey, D.; Puerto, C.; Keefe, T.; Bigelow, P.; Herron, R.; Rosecrance, J.; Chen, P. Comparative Analysis of Safety Culture Perceptions among HomeSafe Managers and Workers in Residential Construction. J. Constr. Eng. Manag. 2012, 138, 1044-1052. [CrossRef]

9. Chen, Q.; Jin, R. A comparison of subgroup construction workers' perceptions of a safety program. Saf. Sci. 2015, 74, 15-26. [CrossRef]

10. Hon, C.; Chan, A.; Yam, M. Determining Safety Climate Factors in the Repair, Maintenance, Minor Alteration, and Addition Sector of Hong Kong. J. Constr. Eng. Manag. 2013, 139, 519-528. [CrossRef]

11. Mearns, K.; Flin, R. Assessing the state of organizational safety-Culture or climate? Curr. Psychol. 1999, 18, 5-17. [CrossRef]

12. Chan, A.; Javed, A.; Wong, F.; Hon, C.; Lyu, S. Evaluating the Safety Climate of Ethnic Minority Construction Workers in Hong Kong. J. Prof. Issues Eng. Educ. Pract. 2017, 143, 04017006. [CrossRef]

13. Zhang, R.; Lingard, H.; Nevin, S. Development and validation of a multilevel safety climate measurement tool in the construction industry. Constr. Manag. Econ. 2015, 33, 818-839. [CrossRef]

14. Solís-Carcaño, R.; Franco-Poot, R. Construction Workers' Perceptions of Safety Practices: A Case Study in Mexico. J. Build. Constr. Plan. Res. 2014, 2, 43854. [CrossRef]

15. Panuwatwanich, K.; Al-Haadir, S.; Stewart, R. Influence of safety motivation and climate on safety behaviour and outcomes: Evidence from the Saudi Arabian construction industry. Int. J. Occup. Saf. Ergon. 2017, 23, 60-75. [CrossRef] [PubMed]

16. Lingard, H.; Zhang, R.; Oswald, D. Effect of leadership and communication practices on the safety climate and behaviour of construction workgroups. Eng. Constr. Archit. Manag. 2019, 26, 886-906. [CrossRef]

17. Chen, W.; Merrett, H.; Huang, Y.; Lu, S.; Sun, W.; Li, Y. Exploring the Multilevel Perception of Safety Climate on Taiwanese Construction Sites. Sustainability 2019, 11, 4596. [CrossRef]

18. Lingard, H.; Cooke, T.; Blismas, N. Do Perceptions of Supervisors' Safety Responses Mediate the Relationship between Perceptions of the Organizational Safety Climate and Incident Rates in the Construction Supply Chain? J. Constr. Eng. Manag. 2012, 138, 234-241. [CrossRef]

19. Xia, N.; Xie, Q.; Hu, X.; Wang, X.; Meng, H. A dual perspective on risk perception and its effect on safety behavior: A moderated mediation model of safety motivation, and supervisor's and coworkers' safety climate. Accid. Anal. Prev. 2020, 134, 105350. [CrossRef]

20. Huang, Y.; Jeffries, S.; Tolbert, G.; Dainoff, M. Safety climate: How Can You Measure It \& Why Does It Matter? Prof. Saf. 2017, 62, 28-35.

21. Chen, W.; Lu, C.; Liu, S.; Wang, M. Measuring the perception of safety among Taiwan construction managers. J. Civ. Eng. Manag. 2013, 19, 37-48. [CrossRef] 
22. Elmoujaddidi, F.; Bachir, A. Perceived risk, safety climate and safety behavior on Moroccan construction sites. Int. J. Occup. Saf. Ergon. 2020, 26, 121-128. [CrossRef]

23. Mosly, I. Safety Performance in the Construction Industry of Saudi Arabia. Int. J. Constr. Eng. Manag. 2015, 4, 238-247. [CrossRef]

24. Abukhashabah, E.; Summan, A.; Balkhyour, M. Occupational accidents and injuries in construction industry in Jeddah city. Saudi J. Biol. Sci. 2020, 27, 1993-1998. [CrossRef]

25. Al-Shayea, A.; Ramadan, M.; Al-Yami, K. Structural model of factors contributing to the motivational problem of taking shortcuts at construction workplaces in the Kingdom of Saudi Arabia. Heliyon 2019, 5, e01220. [CrossRef]

26. Erogul, M.; Alyami, M. Construction site safety in small construction companies in Saudi Arabia. Int. J. Manag. Pract. 2017, 10, 406-421. [CrossRef]

27. Sanni-Anibire, M.; Mahmoud, A.; Hassanain, M.; Almutairi, F. Health Aad Safety Perception of Construction Workers in Saudi Arabia. Archit. Civ. Eng. Environ. 2018, 11, 107-118.

28. Al-Haadir, S.; Panuwatwanich, K.; Stewart, R. Empirical Analysis of the Impacts of Safety Motivation and Safety Climate on Safety Behaviour. In Proceedings of the 19th CIB World Building Congress, Brisbane, Australia, 5-9 May 2013.

29. Schwatka, N.; Rosecrance, J. Safety climate and safety behaviors in the construction industry: The importance of co-workers commitment to safety. Work 2016, 54, 401-413. [CrossRef]

30. Lyu, S.; Hon, C.K.; Chan, A.; Wong, F.; Javed, A. Relationships among Safety Climate, Safety Behavior, and Safety Outcomes for Ethnic Minority Construction Workers. Int. J. Environ. Res. Public Health 2018, 15, 484. [CrossRef]

31. Smith, G.; Huang, Y.; Ho, M.; Chen, P. The relationship between safety climate and injury rates across industries: The need to adjust for injury hazards. Accid. Anal. Prev. 2006, 38, 556-562. [CrossRef]

32. Fang, D.; Chen, Y.; Wong, L. Safety Climate in Construction Industry: A Case Study in Hong Kong. J. Constr. Eng. Manag. 2006, 132, 573-584. [CrossRef]

33. Gillen, M.; Baltz, D.; Gassel, M.; Kirsch, L.; Vaccaro, D. Perceived safety climate, job demands, and coworker support among union and nonunion injured construction workers. J. Saf. Res. 2002, 33, 35-51. [CrossRef]

34. Silver, S.; Boiano, J. Differences in Safety Climate Perception by Health Care Worker, Work Schedule, and Workplace Characteristics. Am. J. Med. Qual. 2019, 34, 165-175. [CrossRef]

35. Faqeeh, F.; Khalid, K.; Osman, A. Integrating Safety Attitudes and Safety Stressors into Safety Climate and Safety Behavior Relations: The Case of Healthcare Professionals in Abu Dhabi. Oman Med. J. 2019, 34, 504-513. [CrossRef]

36. Teo, E.; Feng, Y. The Role of Safety Climate in Predicting Safety Culture on Construction Sites. Archit. Sci. Rev. 2009, 52, 5-16. [CrossRef]

37. CA. Web of Science: Confident Research Begins Here. Available online: https://clarivate.com/ webofsciencegroup/solutions/web-of-science/ (accessed on 29 July 2020).

38. SDL. Aboutus. Available online: https://portal.sdl.edu.sa/english/aboutus/ (accessed on 1 April 2020).

39. IBM. IBM SPSS Statistics for Windows, Version 22.0; IBM Corp: Armonk, NY, USA, 2013.

40. Field, A. Discovering Statistics Using IBM SPSS Statistics; Sage Publications: Thousand Oaks, CA, USA, 2013.

41. IBM. IBM SPSS Statistics 22 Algorithms; IBM Corporation: Armonk, NY, USA, 2013; p. 1151.

42. Chan, A.; Wong, F.; Hon, C.; Lyu, S.; Javed, A. Investigating ethnic minorities' perceptions of safety climate in the construction industry. J. Saf. Res. 2017, 63, 9-19. [CrossRef] [PubMed]

43. Mohamed, S. Safety Climate in Construction Site Environments. J. Constr. Eng. Manag. 2002, 128, 375-384. [CrossRef]

44. Seo, H.; Lee, Y.; Kim, J.; Jee, N. Analyzing safety behaviors of temporary construction workers using structural equation modeling. Saf. Sci. 2015, 77, 160-168. [CrossRef]

45. Choudhry, R.; Fang, D.; Lingard, H. Measuring Safety Climate of a Construction Company. J. Constr. Eng. Manag. 2009, 135, 890-899. [CrossRef]

46. Wu, C.; Song, X.; Wang, T.; Fang, D. Core Dimensions of the Construction Safety Climate for a Standardized Safety-Climate Measurement. J. Constr. Eng. Manag. 2015, 141, 04015018. [CrossRef]

47. Zhou, Q.; Fang, D.; Mohamed, S. Safety Climate Improvement: Case Study in a Chinese Construction Company. J. Constr. Eng. Manag. 2011, 137, 86-95. [CrossRef] 
48. Zhou, Q.; Fang, D.; Wang, X. A method to identify strategies for the improvement of human safety behavior by considering safety climate and personal experience. Saf. Sci. 2008, 46, 1406-1419. [CrossRef]

49. Cigularov, K.; Lancaster, P.; Chen, P.; Gittleman, J.; Haile, E. Measurement equivalence of a safety climate measure among Hispanic and White Non-Hispanic construction workers. Saf. Sci. 2013, 54, 58-68. [CrossRef]

50. Li, Q.; Ji, C.; Yuan, J.; Han, R. Developing dimensions and key indicators for the safety climate within China's construction teams: A questionnaire survey on construction sites in Nanjing. Saf. Sci. 2017, 93, 266-276. [CrossRef]

51. Nadhim, E.; Hon, C.; Xia, B.; Stewart, I.; Fang, D. Investigating the Relationships between Safety Climate and Safety Performance Indicators in Retrofitting Works. Constr. Econ. Build. 2018, 18, 110-129. [CrossRef]

52. Zhu, C.; Fan, D.; Fu, G.; Clissold, G. Occupational safety in China: Safety climate and its influence on safety-related behavior. China Inf. 2010, 24, 27-59. [CrossRef]

53. Zahoor, H.; Chan, A.; Utama, W.; Gao, R.; Zafar, I. Modeling the Relationship between Safety Climate and Safety Performance in a Developing Construction Industry: A Cross-Cultural Validation Study. Int. J. Environ. Res. Public Health 2017, 14, 351. [CrossRef] [PubMed]

54. Marín, L.; Lipscomb, H.; Cifuentes, M.; Punnett, L. Associations between safety climate and safety management practices in the construction industry. Am. J. Ind. Med. 2017, 60, 557-568. [CrossRef]

55. Patel, D.; Jha, K. Neural Network Model for the Prediction of Safe Work Behavior in Construction Projects. J. Constr. Eng. Manag. 2015, 141, 04014066. [CrossRef]

56. Guo, B.; Yiu, T.; González, V. Predicting safety behavior in the construction industry: Development and test of an integrative model. Saf. Sci. 2016, 84, 1-11. [CrossRef]

57. Jiang, L.; Yu, G.; Li, Y.; Li, F. Perceived colleagues' safety knowledge/behavior and safety performance: Safety climate as a moderator in a multilevel study. Accid. Anal. Prev. 2010, 42, 1468-1476. [CrossRef]

58. Alruqi, W.; Hallowell, M.; Techera, U. Safety climate dimensions and their relationship to construction safety performance: A meta-analytic review. Saf. Sci. 2018, 109, 165-173. [CrossRef]

59. Marín, L.; Lipscomb, H.; Cifuentes, M.; Punnett, L. Perceptions of safety climate across construction personnel: Associations with injury rates. Saf. Sci. 2019, 118, 487-496. [CrossRef]

60. Jafari, M.; Gharari, M.; Ghafari, M.; Omidi, L.; Kalantari, S.; Fardi, G. The Influence of Safety Training on Safety Climate Factors in a Construction Site. Int. J. Occup. Hyg. 2014, 6, 81-87.

61. Newaz, M.; Davis, P.; Jefferies, M. Developing a safety climate factor model in construction research and practice A systematic review identifying future directions for research. Eng. Constr. Archit. Manag. 2018, 25, 738-757. [CrossRef]

62. Pousette, A.; Larsson, S.; Torner, M. Safety climate cross-validation, strength and prediction of safety behaviour. Saf. Sci. 2008, 46, 398-404. [CrossRef]

63. Judge, J.; Mosher, G.; Simpson, S. Use of Exploratory Factor Analysis to Identify Factors Influencing Safety Climate in Two Work Environments. J. Technol. Manag. Appl. Eng. 2019, 35, 2.

64. Gao, R.; Chan, A.; Utama, W.; Zahoor, H. Multilevel Safety Climate and Safety Performance in the Construction Industry: Development and Validation of a Top-Down Mechanism. Int. J. Environ. Res. Public Health 2016, 13, 1100. [CrossRef] [PubMed]

65. Low, B.; Man, S.; Chan, A.; Alabdulkarim, S. Construction Worker Risk-Taking Behavior Model with Individual and Organizational Factors. Int. J. Environ. Res. Public Health 2019, 16, 1335. [CrossRef]

66. Pousette, A.; Torner, M. Effects of systematic work preparation meetings on safety climate and psychosocial conditions in the construction industry. Constr. Manag. Econ. 2016, 34, 355-365. [CrossRef]

67. Cigularov, K.; Adams, S.; Gittleman, J.; Haile, E.; Chen, P. Measurement equivalence and mean comparisons of a safety climate measure across construction trades. Accid. Anal. Prev. 2013, 51, 68-77. [CrossRef]

68. Hon, C.; Liu, Y. Exploring Typical and Atypical Safety Climate Perceptions of Practitioners in the Repair, Maintenance, Minor Alteration and Addition (RMAA) Sector in Hong Kong. Int. J. Environ. Res. Public Health 2016, 13, 935. [CrossRef]

69. Chen, Q.; Jin, R. Multilevel Safety Culture and Climate Survey for Assessing New Safety Program. J. Constr. Eng. Manag. 2013, 139, 805-817. [CrossRef]

70. He, Q.; Dong, S.; Rose, T.; Li, H.; Yin, Q.; Cao, D. Systematic impact of institutional pressures on safety climate in the construction industry. Accid. Anal. Prev. 2016, 93, 230-239. [CrossRef] [PubMed]

71. Newaz, M.; Davis, P.; Jefferies, M.; Pillay, M. Using a psychological contract of safety to predict safety climate on construction sites. J. Saf. Res. 2019, 68, 9-19. [CrossRef] [PubMed] 
72. Stoilkovska, B.; Pancovska, V.; Mijoski, G. Relationship of safety climate perceptions and job satisfaction among employees in the construction industry: The moderating role of age. Int. J. Occup. Saf. Ergon. 2015, 41, 440-447. [CrossRef]

73. Hon, C.; Hinze, J.; Chan, A. Safety climate and injury occurrence of repair, maintenance, minor alteration and addition works: A comparison of workers, supervisors and managers. Facilities 2014, 32, 188-207. [CrossRef]

74. Newaz, M.; Davis, P.; Jefferies, M.; Pillay, M. The psychological contract: A missing link between safety climate and safety behaviour on construction sites. Saf. Sci. 2019, 112, 9-17. [CrossRef]

75. Chen, Y.; McCabe, B.; Hyatt, D. A resilience safety climate model predicting construction safety performance. Saf. Sci. 2018, 109, 434-445. [CrossRef]

76. Loosemore, M.; Sunindijo, R.; Lestari, F.; Kusminanti, Y.; Widanarko, B. Comparing the safety climate of the Indonesian and Australian construction industries Cultural and institutional relativity in safety research. Eng. Constr. Archit. Manag. 2019, 26, 2206-2222. [CrossRef]

77. Wu, X.; Yin, W.; Wu, C.; Luo, X. The Spillover Effects on Employees' Life of Construction Enterprises' Safety Climate. Sustainability 2017, 9, 2060. [CrossRef]

78. Alidrisi, H.; Mohamed, S. Systematic Review of Safety Leadership: A Fresh Perspective. In Proceedings of the 8th International Conference on Engineering Project, and Product Management, Amman, Jordan, 19-21 September 2017.

79. Glendon, A.; Litherland, D. Safety climate factors, group differences and safety behaviour in road construction. Saf. Sci. 2001, 39, 157-188. [CrossRef]

80. Wu, X.; Liu, Q.; Zhang, L.; Skibniewski, M.; Wang, Y. Prospective safety performance evaluation on construction sites. Accid. Anal. Prev. 2015, 78, 58-72. [CrossRef]

81. Siu, O.; Phillips, D.; Leung, T. Safety climate and safety performance among construction workers in Hong Kong The role of psychological strains as mediators. Accid. Anal. Prev. 2004, 36, 359-366. [CrossRef]

82. Melia', J.; Mearns, K.; Silva, S.; Lima, M. Safety climate responses and the perceived risk of accidents in the construction industry. Saf. Sci. 2008, 46, 949-958. [CrossRef]

83. Boshoff, D.; Krugell, C.; Heerden, H. Characteristics of the safety climate in teams with world-class safety performance on construction projects in South Africa. Acta Structilia 2017, 24, 99-127. [CrossRef]

84. Mobaraki, A.; Mirzaei, R.; Ansari, H. A Survey of Health, Safety and Environment (HSE) Management and Safety Climate in Construction Sites. Eng. Technol. Appl. Sci. Res. 2017, 7, 1334-1337.

85. Pandit, B.; Albert, A.; Patil, Y.; Al-Bayati, A. Fostering Safety Communication among Construction Workers: Role of Safety Climate and Crew-Level Cohesion. Int. J. Environ. Res. Public Health 2019, 16, 71. [CrossRef]

86. Shen, Y.; Ju, C.; Koh, T.; Rowlinson, S.; Bridge, A. The Impact of Transformational Leadership on Safety Climate and Individual Safety Behavior on Construction Sites. Int. J. Environ. Res. Public Health 2017, 14, 45. [CrossRef]

87. Greeff, W. The role of communication in managing the safety climate of construction site environments. Communicatio 2017, 43, 103-121. [CrossRef]

88. Pinion, C.; Klyza, J.; Brewer, S.; Douphrate, D. North American Engineering, Procurement, Fabrication and ConstructionWorker Safety Climate Perception Affected by Job Position. Safety 2018, 4, 14. [CrossRef]

89. Lingard, H.; Cooke, T.; Blismas, N. Group-level safety climate in the Australian construction industry: Within-group homogeneity and between-group differences in road construction and maintenance. Constr. Manag. Econ. 2009, 27, 419-432. [CrossRef]

90. Lingard, H.; Cooke, T.; Blismas, N. Properties of group safety climate in construction: The development and evaluation of a typology. Constr. Manag. Econ. 2010, 28, 1099-1112. [CrossRef]

91. Lingard, H.; Cooke, T.; Blismas, N. Safety climate in conditions of construction subcontracting: A multi-level analysis. Constr. Manag. Econ. 2010, 28, 813-825. [CrossRef]

92. Chen, Y.; McCabe, B.; Hyatt, D. Impact of individual resilience and safety climate on safety performance and psychological stress of construction workers: A case study of the Ontario construction industry. J. Saf. Res. 2017, 61, 167-176. [CrossRef] [PubMed]

93. Stiehl, E.; Forst, L. Safety Climate Among NontraditionalWorkers in Construction: Arguing for a Focus on Construed External Safety Image. New Solut. A J. Environ. Occup. Health Policy 2018, 28, 33-54. [CrossRef] [PubMed]

94. Larsson, S.; Pousette, A.; Torner, M. Psychological climate and safety in the construction industry-mediated influence on safety behaviour. Saf. Sci. 2008, 46, 405-412. [CrossRef] 
95. Lingard, H.; Cooke, T.; Blismas, N. Coworkers' response to occupational health and safety: An overlooked dimension of group-level safety climate in the construction industry? Eng. Constr. Archit. Manag. 2011, 18, 159-175. [CrossRef]

96. He, C.; McCabe, B.; Jia, G.; Sun, J. Effects of Safety Climate and Safety Behavior on Safety Outcomes between Supervisors and Construction Workers. J. Constr. Eng. Manag. 2020, 146, 04019092. [CrossRef]

97. Cheung, C.; Zhang, R. How Organizational Support Can Cultivate a Multilevel Safety Climate in the Construction Industry. J. Manag. Eng. 2020, 36, 04020014. [CrossRef]

98. Yan, X.; Zhang, H.; Li, H. Estimating Worker-Centric 3D Spatial Crowdedness for Construction Safety Management Using a Single 2D Camera. J. Comput. Civ. Eng. 2019, 33, 04019030. [CrossRef]

99. Fargnoli, M.; Lombardi, M. Preliminary Human Safety Assessment (PHSA) for the Improvement of the Behavioral Aspects of Safety Climate in the Construction Industry. Buildings 2019, 9, 69. [CrossRef]

100. Han, Y.; Yin, Z.; Liu, J.; Jin, R.; Gidado, K.; Painting, N.; Yang, Y.; Yan, L. Defining and Testing a Safety Cognition Framework Incorporating Safety Hazard Perception. J. Constr. Eng. Manag. 2019, 145, 04019081. [CrossRef]

101. Fargnoli, M.; Lombardi, M. Building Information Modelling (BIM) to Enhance Occupational Safety in Construction Activities: Research Trends Emerging from One Decade of Studies. Buildings 2020, 10, 98. [CrossRef]

102. Reiman, A.; Pedersen, L.; Väyrynen, S.; Airaksinen, O.; Sormunen, E.; Räsänen, T. Multi-organisational approach to safety training: The case of a Finnish Safety Training Park. Constr. Manag. Econ. 2020, 38, 659-672. [CrossRef]

103. Shohet, I.; Luzi, M.; Tarshish, M. Optimal allocation of resources in construction safety: Analytical-empirical model. Saf. Sci. 2018, 104, 231-238. [CrossRef]

104. Khoshnava, S.; Rostami, R.; Zin, R.; Mishra, A.; Rani, P.; Mardani, A.; Alrasheedi, M. Assessing the impact of construction industry stakeholders on workers' unsafe behaviours using extended decision making approach. Autom. Constr. 2020, 118, 103162. [CrossRef]

105. Paci-Green, R.; Varchetta, A.; McFarlane, K.; Iyer, P.; Goyeneche, M. Comprehensive school safety policy: A global baseline survey. Int. J. Disaster Risk Reduct. 2020, 44, 101399. [CrossRef]

106. Zhang, R.; Lingard, H.; Oswald, D. Impact of Supervisory Safety Communication on Safety Climate and Behavior in Construction Workgroups. J. Constr. Eng Manag. 2020, 146, 04020089. [CrossRef]

107. Pandit, B.; Albert, A.; Patil, Y. Developing construction hazard recognition skill: Leveraging safety climate and social network safety communication patterns. Constr. Manag. Econ. 2020, 38, 640-658. [CrossRef]

108. Zamani, V.; Banihashemi, S.; Abbasi, A. How can communication networks among excavator crew members in construction projects affect the relationship between safety climate and safety outcomes? Saf. Sci. 2020, 128, 104737. [CrossRef]

109. Moaveni, S.; Banihashemi, S.; Mojtahedi, M. A Conceptual Model for a Safety-Based Theory of Lean Construction. Buildings 2019, 9, 23. [CrossRef]

110. Shohet, I.; Wei, H.; Skibniewski, M.; Tak, B.; Revivi, M. Integrated Communication, Control, and Command of Construction Safety and Quality. J. Constr. Eng. Manag. 2019, 145, 04019051. [CrossRef]

(C) 2020 by the authors. Licensee MDPI, Basel, Switzerland. This article is an open access article distributed under the terms and conditions of the Creative Commons Attribution (CC BY) license (http://creativecommons.org/licenses/by/4.0/). 